\title{
Article \\ Ups and Downs of the Italian Locust (Calliptamus italicus L.) Populations in the Siberian Steppes: On the Horns of Dilemmas
}

\author{
Michael G. Sergeev ${ }^{1,2}$ (D) \\ 1 Department of General Biology and Ecology, Novosibirsk State University, 2 Pirogova Street, \\ 630090 Novosibirsk, Russia; mgs@fen.nsu.ru \\ 2 Laboratory of Invertebrate Ecology, Institute of Systematics and Ecology of Animals, Siberian Branch, Russian \\ Academy of Sciences, 11 Frunze Street, 630091 Novosibirsk, Russia
}

\begin{abstract}
The Italian locust is a common species and one of the most important pest in the steppes, semi-deserts, and deserts of Central and Southwestern Asia and also in the Mediterranean Region. The aim of this paper is to discuss some problems arising from studies of eco-geographical distribution and long-term dynamics of this species, especially in the southern part of West Siberia, and their consequences for management of pest species and rare forms. Peculiarities of the Italian locust populations' distribution and long-term dynamics are discussed for the north-eastern part of the species range (south-eastern West Siberian Plain, North-East and, partly, East Kazakhstan). Notable differences between local populations are revealed. Some issues arising from results of insecticide experimental treatments (mainly effectiveness of barrier applications with different compounds in variable environment) and ecological association between the Italian locust and rare Orthoptera are also discussed. Some suggestions as to requirements for improved monitoring, supervision, control, and forecasting of the Italian locust populations' distribution and dynamics are also provided.
\end{abstract}

Citation: Sergeev, M.G. Ups and

Downs of the Italian Locust

(Calliptamus italicus L.) Populations in the Siberian Steppes: On the Horns of Dilemmas. Agronomy 2021, 11, 746. https://doi.org/10.3390/ agronomy11040746

Academic Editor: Salvatore Davino

Received: 2 April 2021

Accepted: 10 April 2021

Published: 12 April 2021

Publisher's Note: MDPI stays neutral with regard to jurisdictional claims in published maps and institutional affiliations.
Keywords: West Siberian Plain; outbreak; distribution; dynamics; population; population management; plant protection

\section{Introduction}

The Italian locust (Calliptamus italicus (Linnaeus, 1758)) is a common and widely distributed species and the most important acridid pest in the steppes and semi-deserts of Eurasia, from Ukraine to the southern part of West Siberia, East Kazakhstan, and NorthWest China. Many of its outbreaks were in these areas, in mountains and oases of Central Asia, and also in the Mediterranean region. In the steppes, during the 20th century, its outbreaks occurred in all decades, but the situation became especially dangerous in the end of the last century, when in 2000 more than 16 million ha were infested and more than 10 million ha were treated by different acridicides from organophosphates to insect growth regulators [1,2].

The Italian locust is an intermediate form between typical gregarious and solitarious acridid species $[1,3,4]$. During outbreaks, the dense bands and swarms are common; however, their dispersal rates are usually limited. Both hopper bands and swarms can migrate over comparatively small distances, usually up to several hundred meters (rarely up to several kilometers) for bands and up to $100-200 \mathrm{~km}$ (rarely up to $750-800 \mathrm{~km}$ ) for swarms [5-7]. Morphologically, the gregarious form of adults may be distinguished only by relatively long wings [3,8]. Gregarious nymphs of the Italian locust are usually characterized by dominance of dark colors (brown, grey, and black) [5,9].

Ecological peculiarities and distribution patterns of C. italicus are described in many publications for some parts of its range. An analysis of many publications was given by B.P. Uvarov [3]. He emphasized an insufficient level of our knowledge on the Italian locust ecology for periods between outbreaks. During recent decades, results of many studies concerning this species were published as well; however, nearly all of them are limited by 
outbreak periods $[1,4,10,11]$. Recently, the main part of all data was summarized for the territory of the former USSR [9].

The Italian locust is a typical univoltine form with overwintering eggs. Its spatial population distribution during periods between outbreaks shows that, in the northern part of its range, the species occurs in very dry habitats, in the central one, it prefers relatively dry and diverse habitats of the steppe and semi-desert life zones, while in the southern part, its colonies are usually localized in meadow habitats of river valleys or in mountains $[4,12]$. The species prefers highly heterogeneous semi-arid landscapes (especially with dominance of sagebrushes-Artemisia spp.) in the dry steppes and the semi-deserts. During outbreaks, the Italian locust can penetrate and colonize different types of fields cultivated and abandoned, and also other types of transformed habitats, e.g., roadsides, lawns, overgrazed sandy plots, etc. However, the Italian locust usually prefers to consume dicotyledon plants, e.g., Artemisia Linnaeus, Lactuca tatarica (Linnaeus) C.A.Mey, Kochia Roth, Medicago Linnaeus, Glyzyrrhiza Linnaeus, etc. [3,9]. This means the species can seriously damage some cash crop fields, for instance, sunflowers, and, at least on the first stage of infestation, may eat and destroy different weeds across wheat fields.

The aim of this paper is to discuss some problems arising from studies of longterm dynamics of the Italian locust populations, especially in the southern part of West Siberia, and their consequences for population management of both possible pest and rare orthopteran species.

\section{Materials and Methods}

\subsection{Study Territory}

Original data were collected from 1979 until 2019 in the south-eastern part of West Siberian Plain and in the adjacent north-eastern and eastern parts of the Kazakh Uplands (Saryarqa). This region borders the Ishim River (left tributary of the Irtysh) to the west and south-west, the southern edge of the Kazakh Uplands to the south, the Altay Mts. to the south-east, and the Ob River to the east. Its northern boundary is approximately defined by the 56th parallel north. Average temperatures are relatively low (mean temperatures of the warmest month vary from 17 to $22^{\circ} \mathrm{C}$, the same for the coldest month-from -17 to $-20^{\circ} \mathrm{C}$ ), and annual precipitation amounts vary from 280 to $520 \mathrm{~mm}$ [13]. Originally, this territory was covered with grasslands (from meadows to semi-deserts) and forests (mainly birch and pine) [13-15]. The main part of the plains was transformed in agricultural lands (fields and pastures), while the mountain steppes and semi-deserts are used for livestock grazing. Besides, there are some flood-plains with meadows and forest patches, sandy plots, solonchaks, and swamps. The Kazakh Uplands consist of small low ranges, numerous hills and small mountains, where some elements of altitudinal zonation may be observed.

\subsection{Observation Sites}

Nine fixed sites were selected to study long-term dynamics of the Italian locust populations in the central part of the so-called Kulunda steppe (between the Irtysh River and the central part of the Altaj Region). Almost all plots were covered by more or less typical steppe zonal vegetation. In some cases, vegetation cover was damaged by moderate grazing or haymaking. These sites were distributed from the northern steppes to the southern ones:

1. SE Aleksandrovskij settlement (Novosibirskaya Oblast (Novosibirsk Region), $53.67^{\circ} \mathrm{N}$ $78.25^{\circ}$ E, northern steppe, studied in 2000-2008, 2015, 2018, 2019; in 2003 the local control, i.e., untreated, plot was moved about $100 \mathrm{~m}$ southwards, because the main part of the area was plowed) (Figure 1A).

2. S Burla settlement (Altai Krai (Altaj Region), $53.23^{\circ} \mathrm{N} 78.43^{\circ}$ E, old abandoned field, 2000-2008).

3. SW Yarovoe town (Altai Krai (Altaj Region), $52.85^{\circ} \mathrm{N} 78.57^{\circ} \mathrm{E}$, dry steppe (actually very old crested wheatgrass field), 1979, 1992, 1999-2008, 2015). 
4. E Platovka settlement (Altai Krai (Altaj Region), 52.40 N 79.05 E, dry steppe, 1999 2008, 2015).

5. SE Severka settlement (Altai Krai (Altaj Region), $52.12^{\circ} \mathrm{N} 79.32^{\circ}$ E, typical steppe, 1999-2008, 2015).

6. S Pokrovka settlement (Altai Krai (Altaj Region), $52.00^{\circ} \mathrm{N} 79.37^{\circ}$ E, typical steppe, 1999-2008, 2015).

7. NW Mikhaylovskoye settlement (Altai Krai (Altaj Region), $51.82^{\circ} \mathrm{N} 79.62^{\circ}$ E, typical steppe, 1999-2008, 2015; in 2003, we counted locusts on the adjacent steppe plot, $51.83^{\circ} \mathrm{N} 79.58^{\circ} \mathrm{E}$, because we could not visit the stationary plot due to some technical problems).

8. W Bor-Forpost settlement (Altai Krai (Altaj Region), $51.87^{\circ} \mathrm{N} 80.03^{\circ}$ E, typical steppe (actually very old crested wheatgrass field), 2000-2009, 2015).

9. E Ust-Volchikha settlement (Altai Krai (Altaj Region), $51.93^{\circ} \mathrm{N} 80.28^{\circ}$ E, dry steppe, 1999-2009, 2015, 2018) (Figure 1B).

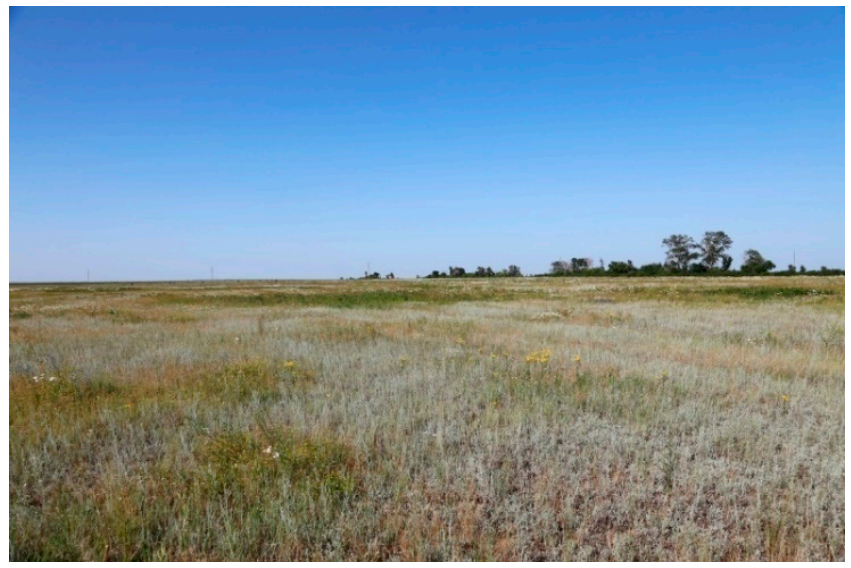

(A)

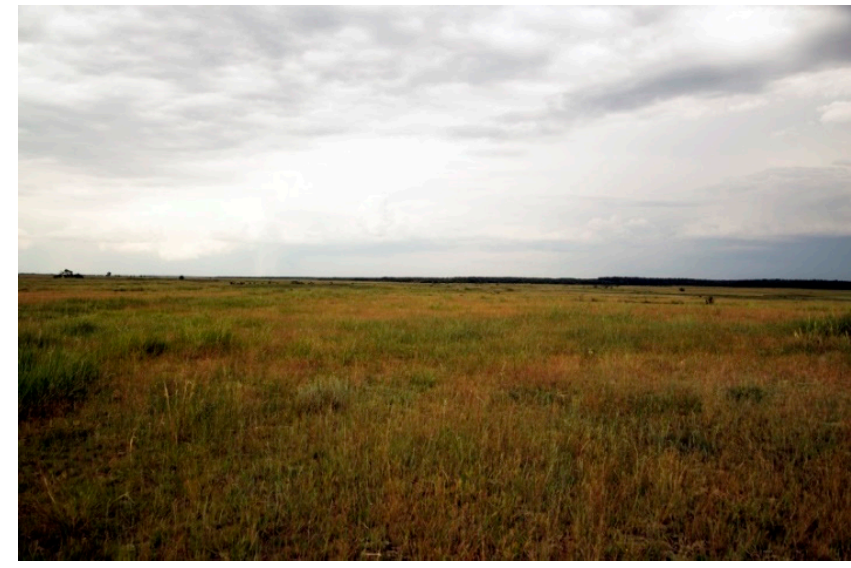

(B)

Figure 1. Typical habitats of the Italian locust in the Kulunda steppe: (A)—northern steppe (near Aleksandrovskij settlement); (B)—dry steppe (near Ust-Volchikha settlement).

As a rule, locust abundance/density was counted in the first half and middle of July, while adults prevailed (see the Section 2.4). In this study, I analyzed data mainly for 2000-2008 when all nine sites were explored.

\subsection{Experimental Area}

In 2000, during the Italian locust outbreak, the dynamics of its local population was studied on the experimental area near Alexandrovskij settlement (see Section 2.2). This area included some plots with steppe vegetation, some agricultural fields, several small birch forests, a shallow depression with halophytes vegetation, meadows and willow bushes, and forest belts [16]. The steppe vegetation was quite diverse and heterogeneous (Figure 2). Several plant species, namely, Phleum phleoides (Linnaeus) H. Karst., Agrostis capillaris Linnaeus, Koeleria macrantha (Ledeb.) Schult., Potentilla argentea Linnaeus, Galium verum Linnaeus, Veronica spuria Linnaeus, Artemisia glauca Pall. ex Willd., A. gr. frigida, were common dominants. The local steppe habitats were used for very moderate livestock grazing and haying. The general distribution of C. italicus was studied over this area in June and July. These studies were continued in 2001 and 2002. Later we checked this population of the Italian locust once a summer, commonly in July. 


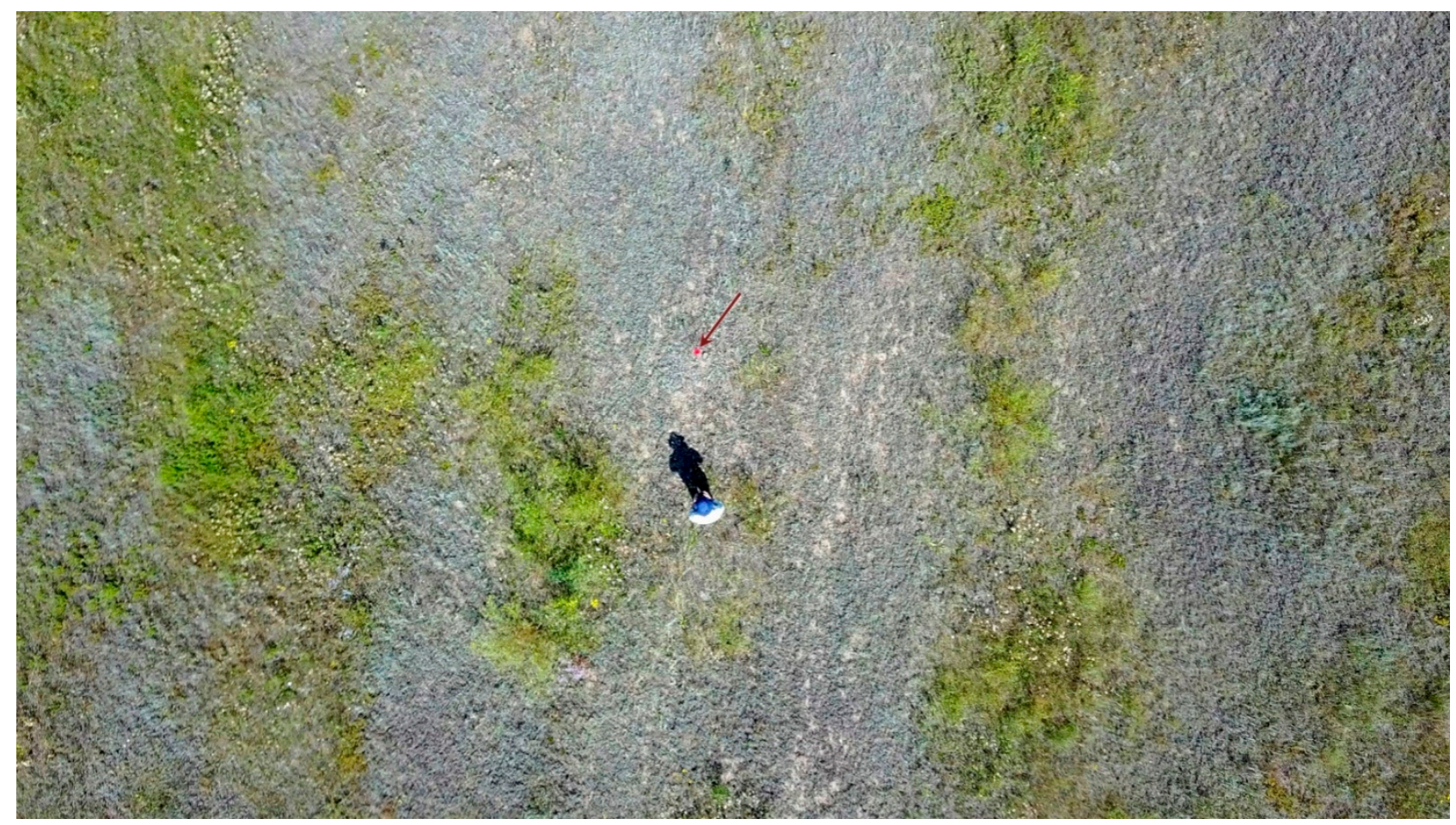

Figure 2. Typical heterogeneous steppe habitat of the Italian locust with vegetation mosaic (grey-short sagebrushes, green-grasses or forbs) in the Kulunda steppe (near Aleksandrovskij settlement): red dot—exact position of an adult (31 July 2019).

In 2000 and 2001, some experimental treatments were organized. The steppe parts were split into several experimental and control plots. In 2000, experiments were conducted with a water-based formulation of fipronil (phenylpyrazole insecticide). The acridicide was applied to $50 \%$ of the main experimental plot, by alternating, 15-m-wide swaths. The dose rate in the "barriers" was $4 \mathrm{~g}$ of a.i. per ha (i.e., $2 \mathrm{~g}$ of a.i. per protected ha). In 2001 the main experiments included different types of treatments with a suspension formulation of teflubenzuron (insect grow regulator-IGR). Four experimental treatments were conducted: (1) blanket, (2) barrier (alternating swaths of $15 \mathrm{~m}$ wide), (3) alternating treated (15 m) and untreated $(30 \mathrm{~m})$ swaths, and (4) alternating treated $(15 \mathrm{~m})$ and untreated $(45 \mathrm{~m})$ swaths. The dose rate in the "barriers" was $30 \mathrm{~g}$ of a.i./ha, while the rate in the "blanket" area was $22.5 \mathrm{~g}$ of a.i./ha. In 2003, some parts of the experimental area (north-eastern and south-western) were plowed to cultivate perennial grasses (mainly Bromus inermis Leyss.) However, after several years, the steppe vegetation has been recovered almost completely.

\subsection{Field Studies}

General distribution patterns of the Italian locust over the south-eastern part of West Siberian Plain and the adjacent north-eastern and eastern parts of the Kazakh Uplands were revealed on the basis of quantitative and qualitative samples collected in natural and transformed ecosystems, usually in the middle of summer when adults were dominant.

Field sampling was organized along gradient (usually transzonal), regional and local transects [4,17]. Each transzonal transect crossed the set of life zones, e.g., from the southern taiga to the northern deserts, and consisted of the set of regional and local transects. Each regional transect laid out a geographic region (e.g., the Kulunda steppe), commonly along river valleys, and was composed of local transects. Each local transect crossed a river valley or a lake basin from a local lower flood-plain to a watershed plain (plakor or flat interfluve) or mountain slopes. The length of local transects was from hundreds of meters to several kilometers. Grass ecosystems and similar transformed habitats were studied along local transects. As a rule, each part (habitat) of the local transect (lower and upper 
flood-plains, lower and upper terraces, watershed plain, in some cases, their variants) was explored separately. Samples captured during a fixed period of time were made in every habitat studied $[4,17,18]$. Using this method, insects were captured with a standard net (40 cm diameter) over a period of 10-30 min. Results for each habitat were extrapolated to an hour. In some cases, a simple sweep netting was used too. Many habitats were also investigated to find species with very low abundance. This approach allowed us to obtain repeatable and comparable results over a number of years and habitats and independently of collectors (Figure 3).

1975197619861991

southern slope
piedmont plain
upper terraces
lower terraces
upper flood-plains
lower flood-plains

\begin{tabular}{|c|c|c|c|}
\hline$?$ & & & \\
\hline & & & \\
\hline$?$ & & & \\
\hline & & $?$ & $?$ \\
\hline & & & \\
\hline & & & \\
\hline
\end{tabular}

low level of abundance, 1-19 ind. per hour

medium level of abundance, 20-99 ind. per hour

high level of abundance, more than 99 ind. per hour

Figure 3. Population distribution of the Italian locust along the local transect crossing the Ayagöz River Valley (semi-desert, eastern part of the Kazakh Uplands, $47.92^{\circ}$ N 80.25 E). Collectors: 1975-I. Stebaev, E. Moiseeva; 1976-A. Lopatkin; 1986 and 1991-M. Sergeev).

Some old data, mainly from the expeditions of Novosibirsk State University (19721977), were also used. We employed the Glonass/GPS receivers to determine geographical coordinates. We also used Google Earth Pro $\left({ }^{\circledR}\right.$ Google, 2020) to get the same parameters for habitats explored before 2000. The main part of studied specimens is in the collections of Novosibirsk State University and the Institute of Systematics and Ecology of Animals (Novosibirsk).

Peculiarities of long-term and seasonal dynamics and results of experimental treatments were revealed on the basis of the Italian locust density estimations. In each habitat studied, locusts were counted on arbitrarily placed plots $0.25 \times 0.25 \mathrm{~m}^{2}$ (in some cases$0.5 \times 0.5 \mathrm{~m}^{2}$ or $\left.1 \times 1 \mathrm{~m}^{2}\right)[4,16,19]$. We determined densities on 25 plots, while locust densities were high, and on 50-200 plots (sometimes more), when densities were low. After that, the average density was estimated for every habitat studied.

\subsection{Data Analysis}

The general distribution patterns of the Italian locust along transects and habitats were analyzed by simple ratio scaling to avoid some problems with variations of abundance estimations $[4,20]$ (see also Figure 3). Three scales were used: from very low up to 19 ind. per hour; from 20 to 99 ind. per hour; more than 99 ind. per hour.

Data on the long-term and seasonal dynamics and results of experimental treatments are commonly non-parametric. The long-term dynamics patterns of the Italian locust populations on the model plots (see Section 2.2) were compared by the Spearman rank order correlation analysis. Significance of difference between years for each model plot was estimated by the Kruskal-Wallis ANOVA and median tests. The Mann-Whitney U test was also calculated for every consecutive pair of years on each plot. The same tests were used for the analysis of seasonal dynamics peculiarities and results of treatments (see Section 2.3). Effectiveness of treatments was estimated by the modified Abbott's formula considering population dynamics on both test and control plots [21]. Data analyses were mainly conducted using PAST 4.02 [22] and Statistica 10 (@ StatSoft. Inc., Tulsa, OK, USA; now- (C) TIBCO Software Inc., Palo Alto, CA, USA).

The tegmen length/posterior femur length ratios $(\mathrm{E} / \mathrm{F})$ were also counted for populations studied [8,19], especially for outbreak seasons. According to K.A. Vasil'ev [8], the typical solitarious specimens have relatively short tegmina ( $\mathrm{E} / \mathrm{F}$ for females $<1.418$ and 
for males $<1.402$ ), and the tegmina of the typical gregarious adults are visibly longer (E/F for females > 1.608; for males > 1.625).

Numerous publications describing the Italian locust spatio-temporal distribution in different parts of its range were also analyzed.

\section{Results}

3.1. Distribution Patterns of the Italian Locust over the South-Eastern Part of West Siberian Plain and the Adjacent North-Eastern and Eastern Parts of the Kazakh Uplands

A comparative analysis of three gradient transects crossing the eastern part of the Italian locust range from the forest-steppes of West Siberian Plain to Central Asia: (1) mainly along the 77-79th meridians east [4,9,12]; (2) along the 80th meridian east (Figure 4B), and (3) along the Irtysh River (Figure 4A)-allowed to reveal the general patterns of the species populations' distribution in the periods between outbreaks.

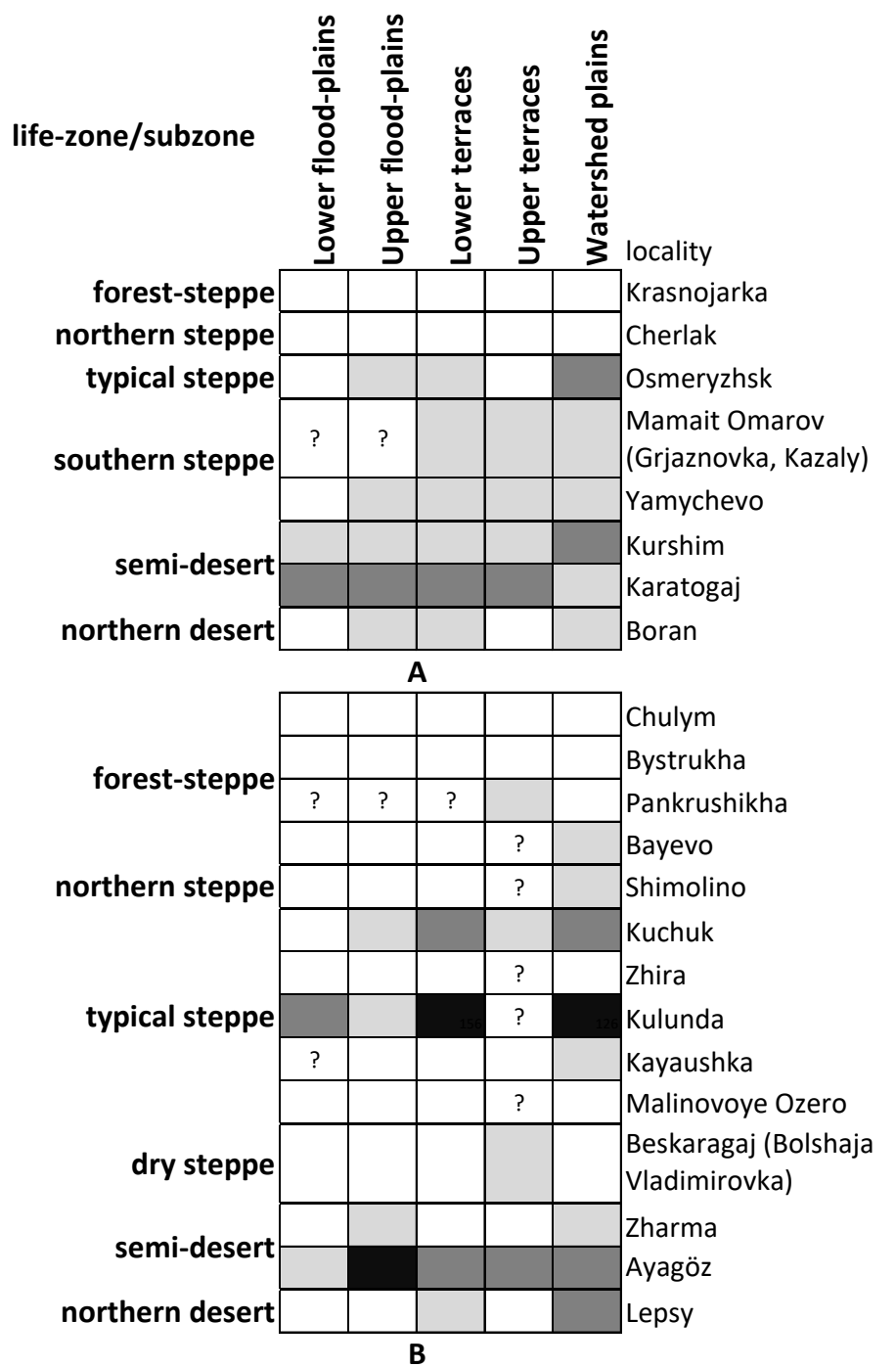

\begin{tabular}{rrr}
$N$ & \multicolumn{2}{c}{ year } \\
55.27 & 73.23 & 1974 \\
54.05 & 74.98 & 1974 \\
53.1 & 75.92 & $1972,1974,1975$ \\
& & \\
51.92 & 77.03 & 1972,1975 \\
51.88 & 77.38 & 1972,1974 \\
48.63 & 83.6 & 1976 \\
48.38 & 84.52 & 1976 \\
48 & 85.15 & 1976 \\
& & 1985 \\
55.08 & 81 & 1985 \\
54.4 & 80.85 & 1992 \\
53.85 & 80.42 & 2019 \\
53.27 & 80.78 & 2018 \\
52.98 & 80 & 2015 \\
52.68 & 80.05 & 2019 \\
52.66 & 79.43 & 1979 \\
52.57 & 79.05 & 1992 \\
52.53 & 80.48 & 2018 \\
51.72 & 79.77 & 1972 \\
& & 1975 \\
50.97 & 79.35 & 1976 \\
48.77 & 80.9 & \\
74.92 & 80.25 & \\
46.2 & 79.22 & \\
& &
\end{tabular}

low level of abundance, 1-19 ind. per hour

medium level of abundance, 20-99 ind. per hour

high level of abundance, more than 99 ind. per hour

Figure 4. Population distribution of the Italian locust along two gradient (transzonal) transects crossing the south-eastern part of West Siberian Plain and the adjacent north-eastern and eastern parts of the Kazakh Uplands along the Irtysh River (A) and near the 80th meridian east (B). N-north; E- east. 
In the southern forest-steppes and in the northern steppes of West Siberia [23], the Italian locust is distributed sporadically, especially during years without outbreaks. Its local colonies occur mainly in dry habitats of watershed plains, including overgrazed pastures and road-sides, while its abundance may be very low. Sometimes a surveyor may spend more than an hour to find one adult. The species is more common in the typical steppes. Its populations are also associated with the steppe habitats on watershed plains, but they are more or less common over terraces and dry parts of upper flood-plains. In the dry steppes of the Kulunda Plain [23], there is the local optimum of the Italian locust. Its populations are in almost all applicable habitats, from flood-plains to watershed plains [6,12,24,25]. In the southernmost steppes and in the northern parts of the semi-deserts, the species colonies occur either in watershed plains and southern slopes of hills or along upper flood-plains. The main optimal area of the Italian locust is in the southern parts of the semi-deserts. Its populations occur in all or almost all favorable habitats, and the abundance level is usually moderate (Figures 3 and 4 ). Further south, its populations are again sporadic and scarce. In the deserts, they are commonly associated with some parts of watershed plains, mountain slopes, and upper floodplains. The sketchy pattern of the Italian locust distribution along the Irtysh River in the 1920s described by G.Ya. Bey-Bienko [26] corresponds mainly to our data (Figure 5).
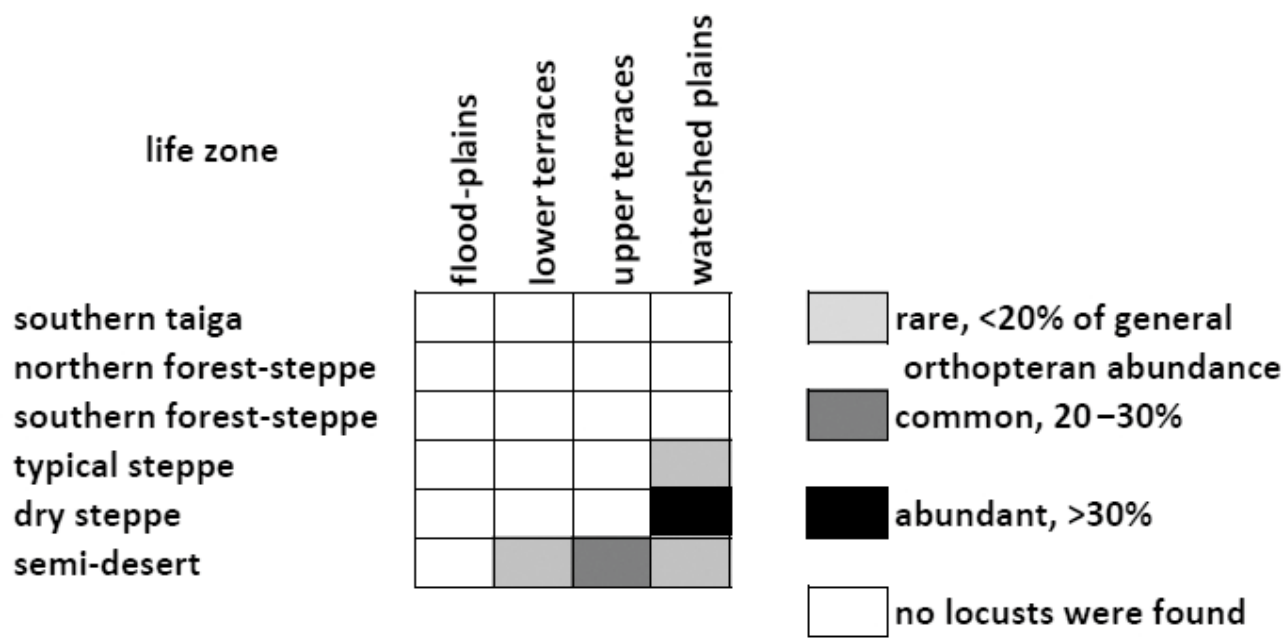

Figure 5. Population distribution of the Italian locust along the Irtysh River in the 1920s (after [26]).

\subsection{Long-Term Dynamics of the Italian Locust in the Central and Eastern Parts of Its Range: General Patterns}

General trends of the Italian locust long-term dynamics were mainly evaluated on the basis of published data [10,11,27-31]. Recently many of them were described for the main regions of the former USSR countries [9].

In the 19th century, the situation with the Italian locust and other grasshoppers in the Russian Empire was relatively calm. Many acridid outbreaks were registered in 1821-1830 and 1841-1850. However, K. Lindemann [27] described in detail a series of outbreaks of the Italian locust per se in the forest-steppes of European Russia. The situation changed during the next century. Some serious outbreaks occurred in 1921-1940. However, the Italian locust had remained the secondary pest.

For instance, in the comprehensive report on the acridid pests of the USSR for 1925-1933 [29], authors described the problems associated with the migratory locust, Locusta migratoria (Linnaeus), on 32 pages, with the Moroccan locust, Dociostaurus maroccanus (Thunberg) — on 33 pages, and even with the desert locust, Schistocerca gregaria (Forskål)— on four pages, while the part concerning the Italian locust took up slightly more than one page only. As a rule, the breeding areas of $C$. italicus were localized and limited by hundreds or thousands hectares, mainly in the semi-deserts [28]. For instance, during the 
outbreak in 1932-1933 in Kazakhstan, the general infested area was less than 190,000 ha (cf. with the area infested in 2000-more than 8 million ha [1]). However, its local bands and swarms were characterized by very high densities and active migrations, especially in the semi-deserts.

From 1940 until 1990 upsurges had been more or less common but remained highly localized. However, at the end of the 20th century, the outbreaks became extremely serious and common. For the North Caucasus-Lower Volga area, M.V. Stolyarov [10,11] described four outbreaks of the Italian locust (in 1954-1957, 1972-1974, 1982-1984, and 1992-1998). However, in the southern part of West Siberia, the outbreaks occurred in 1952-1956, 1967-1971, 1977-1982, and 1999-2002 [9]. Thus, the outbreaks of the Italian locust did not exactly coincide in the different part of its range. In many cases, outbreaks in West Siberia started earlier than in the North Caucasus-Lower Volga region, but, as a rule, were relatively weak and sporadic. However, the last and worst outbreak had begun in 1991 in the North Caucasus-Lower Volga region. After that, the outbreak spread over a huge area from Azov Sea to the eastern part of Kazakhstan (1996-1998). In 1998-2001 the main breeding areas moved northward and eastward. On the last stage (2002-2014), these areas became smaller and occupied the territory from south Ukraine to Caspian Sea and to the Ural Mts. [9]. The last decade is characterized by some sporadic outbreaks of the Italian locust in the central and eastern parts of its range, e.g., mainly in some regions of the North Caucasus [32-34].

Thus, the long-term population dynamics of the Italian locust can be very distinct in the different part of its range. Such pattern may be determined by regional climatic peculiarities, by variations in soils and vegetation covering, and by some changes in human activities.

3.3. Peculiarities of Long-Term Dynamics of the Italian Locust in the South-Eastern Part of West Siberian Plain and in the Adjacent Parts of the Kazakh Uplands

The south-eastern part of West Siberian Plain and the adjacent parts of the Kazakh Uplands are the typical territories where outbreaks of the Italian locust began and may begin $[1,4,6,9,30,35,36]$. First data on its local outbreaks appeared in the 1910-1930s [29,30,37,38]. However, these outbreaks were sporadic and restricted by one or a few years $[29,30]$. In the 1930s I.A. Chetyrkina [36] studied the Italian locust distribution in the semi-deserts and in the dry steppes of the eastern part of Kazakhstan. She revealed the main peculiarities of its population distribution when its colonies were found in almost all habitats except pine forests and some plots with halophytes. Actually, her observations showed the Italian locust preferred habitats with sagebrush dominance, including abandoned fields. These shifts in the Italian locust distributions could be associated with some transformation of the territory, because in the beginning of the 20th century, many areas had been plowed, and after that, many fields had become abandoned.

Later, in the middle of the 1950s, during the co-called Virgin Land campaign, vast steppe areas have been plowed and many remaining steppe habitats have become overgrazed. As a result, many habitats of $C$. italicus have been destroyed or damaged. Such regional and local transformations and/or also climate changes could and can result in some shifts in its population dynamics and spatial distribution (Figure 6). Extensive plowing often resulted in very significant decreasing of grasshopper abundance, especially over steppe regions [39]. 


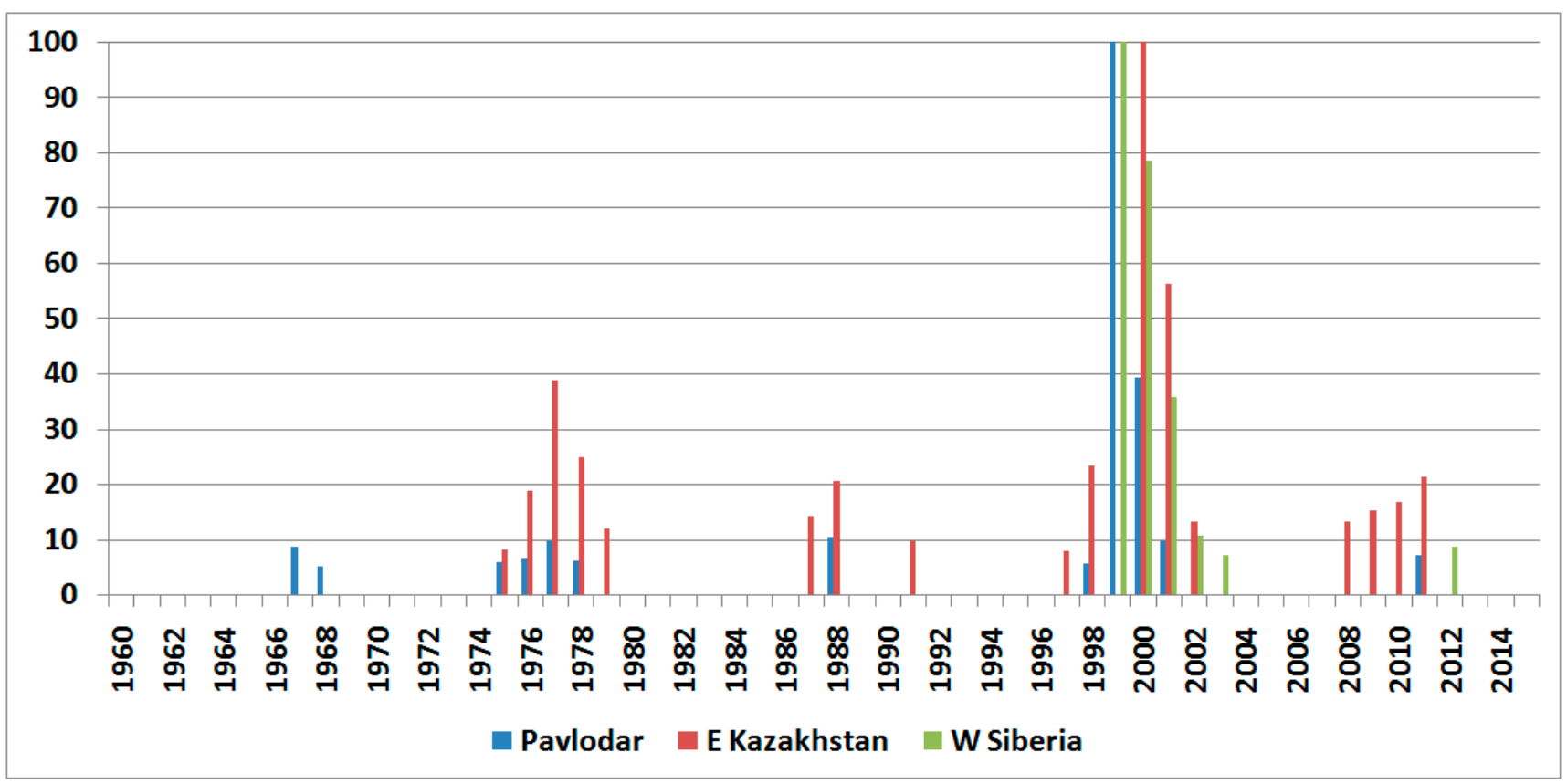

Figure 6. Long-term dynamics (1960-2015) of the Italian locust infestations in West Siberia (Altaj, Novosibirsk and Omsk Regions of Russia) and in the Pavlodar and East Kazakhstan Regions of Kazakhstan (\% of the maximal registered infested areas [9]).

Later, in the 1960-1980s, some development of technologies preventing soil erosion caused again local but relatively weak and rare outbreaks of grasshoppers and locust, including C. italicus [6], but mainly in the semi-deserts of East Kazakhstan. The last and most devastating outbreak of the Italian locust started in 1998. The maximal infested areas were registered in 1999 in the Pavlodar Region and in the south-eastern parts of West Siberia (i.e., mainly in the steppes) and in 2000 in East Kazakhstan (i.e., in the semi-deserts). This outbreak may be qualified as a plague, because the large-scale infestation occupied huge areas and continued at least three years $[1,9,16]$. Besides, there were numerous bands and swarms in almost all parts of the territory, except local forests and the upper altitudinal belts of mountains. Some swarms actively migrated and could cross the state and regional borders. This extreme outbreak might be promoted either by economical transformations in the former USSR countries in the 1990s, while plant protection services were partly destroyed, trans-boundary cooperation in breeding areas was limited, and abandoned fields spread over huge territories, or by climatic changes of recent decades as well [1].

\subsection{Dynamics of the Italian Locust Populations in the Kulunda Steppe in 2000-2008}

In the Kulunda steppe, the last outbreak started in 1999. This area might be colonized by a specific mixture of local and vagrant populations [19,35], but our observations showed the low possibility of long migrations (cf. [36]). The Italian locust occurred in natural, semi-natural and anthropogenic habitats, including cultivated and abandoned fields. In 1999-2000, the average densities of the Italian locust were usually about $0.3-9.6$ adults $/ \mathrm{m}^{2}$, but in some places, the density was significantly higher $\left(\sim 24\right.$ adults $\left./ \mathrm{m}^{2}\right)[16,19]$. Swarms of this species were common in 2000 and 2001. In 2000, they had occupied about $84 \mathrm{~km}$ (from $337 \mathrm{~km}$ ) along a road from Ust-Volchikha to Aleksandrovskij (see Section 2.2), while in 2001 the swarms were observed over a distance of $60 \mathrm{~km}$. Later, in 2002-2008, there were no swarms along this route. However, in 2015, very small bands (up to several square meters) were observed near Severka and Bor-Forpost.

Dynamics patterns were different in all observation sites (Table 1). One can formally split them into four groups based on the position of the maximum average population density. The first group includes the majority of studied populations (Aleksandrovskij, 
Burla, Yarovoe, Platovka, and Mikhaylovskoye). They were at maximum levels during 2000. This group includes mainly the populations from the northern part of the Kulunda steppe, except Mikhaylovskoye. The other groups had the maximum densities of the Italian locust in 2001 (Severka), in 2002 (Bor-Forpost and Ust-Volchikha), and in 2000 and 2002 (Pokrovka), respectively.

This grouping is partly supported by the Spearman rank order correlation analysis (Rs from 0.900 up to 0.975 at the significance level $p<0.05$ ) for 2000-2004 (Figure 7) [19]. The analysis of relatively long rows of data (from 2000-2005 to 2000-2008) allows to gradually combine almost all populations (except Bor-Forpost) but with less significant support (Rs $>0.7, p<0.05$ ) (Figure 7). Such similarity is determined by low levels of population densities from 2003 until 2008 in almost all sites. The population near Bor-Forpost only was characterized by more or less gradually increasing from 2003 until 2008 (actually this trend continued in 2009, with the average density $2.69 \pm 0.54$ ).
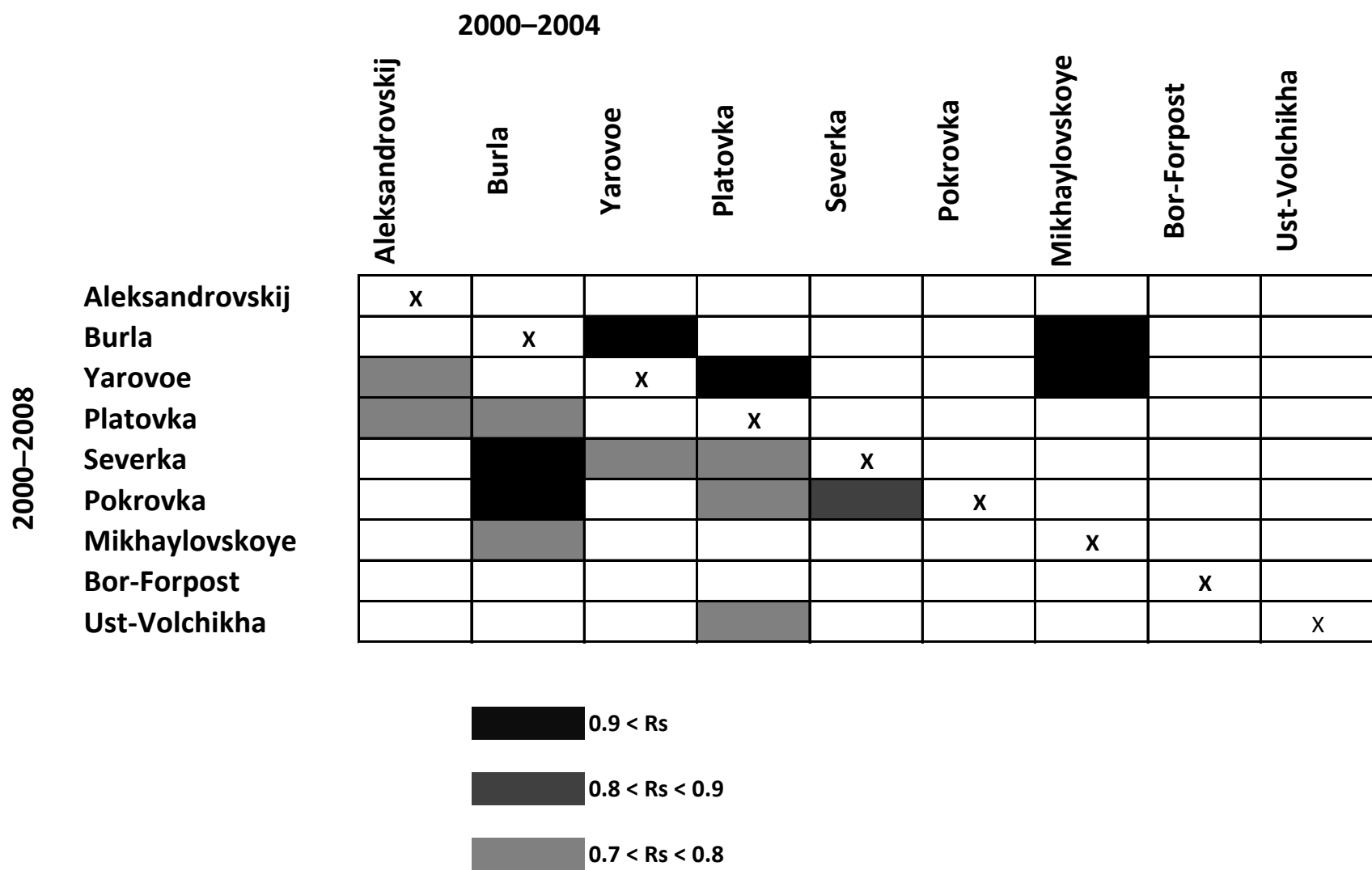

Figure 7. Associations between the long-term dynamics of the Italian locust populations in the Kulunda steppe for 2000-2004 and 2000-2008 (levels of the Spearman rank order correlation-Rs, $p<0.05$ ).

The Kruskal-Wallis ANOVA and median tests show significant inter-annual difference for each site studied at $p<0.0001$ for all tests. Thus, in all cases, the null hypotheses (the different samples are from the same distribution) should be rejected. The Mann-Whitney $\mathrm{U}$ test calculated for every consecutive pair of years for each population (Table 2) reveals significant differences between years with high densities and the adjacent ones for almost all populations [19]. In all cases, variations between consecutive years with densities lower than 3.0 ind. per $\mathrm{m}^{2}$ are insignificant. 
Table 1. Dynamics of the average densities (ind. per $\mathrm{m}^{2} \pm$ s.e.) of the Italian locust in the Kulunda steppe.

\begin{tabular}{|c|c|c|c|c|c|c|c|c|c|}
\hline Year & Aleksandrovskij & Burla & Yarovoe & Platovka & Severka & Pokrovka & Mikhaylovskoye & Bor-For- post & Ust-Volchikha \\
\hline 1999 & $?$ & $?$ & $0.48 \pm 0.27$ & $0.80 \pm 0.33$ & $0.32 \pm 0.22$ & $\sim 1$ & $3.2 \pm 0.61$ & $?$ & $0.32 \pm 0.22$ \\
\hline 2000 & $24.32 \pm 2.34$ & $9.60 \pm 0.85$ & $6.40 \pm 0.65$ & $4.48 \pm 0.48$ & $2.88 \pm 0.67$ & $5.28 \pm 0.86$ & $6.56 \pm 0.80$ & $0.96 \pm 0.35$ & $0.48 \pm 0.27$ \\
\hline 2002 & $0.16 \pm 0.16$ & $3.20 \pm 1.31$ & $0.16 \pm 0.16$ & $1.28 \pm 0.89$ & $1.92 \pm 1.06$ & $6.40 \pm 1.85$ & $0.32 \pm 0.32$ & $1.92 \pm 0.74$ & $1.92 \pm 1.06$ \\
\hline 2003 & + & $0.16 \pm 0.16$ & + & $0.16 \pm 0.16$ & $0.32 \pm 0.23$ & $0.13 \pm 0.13$ & $0.16 \pm 0.16$ & $0.32 \pm 0.23$ & 0 \\
\hline 2004 & $0.32 \pm 0.32$ & + & + & $0.96 \pm 0.54$ & + & 0 & 0 & $0.40 \pm 0.27$ & $0.32 \pm 0.32$ \\
\hline 2005 & $0.32 \pm 0.23$ & 0 & $0.38 \pm 0.22$ & $0.53 \pm 0.37$ & $0.05 \pm 0.05$ & 0 & 0 & $0.85 \pm 0.29$ & + \\
\hline 2006 & + & $0.64 \pm 0.45$ & $0.21 \pm 0.15$ & $0.43 \pm 0.30$ & $1.28 \pm 0.62$ & $0.21 \pm 0.21$ & 0 & $0.75 \pm 0.028$ & $0.16 \pm 0.16$ \\
\hline 2007 & $0.32 \pm 0.23$ & $0.96 \pm 0.54$ & $0.64 \pm 0.32$ & $1.16 \pm 0.69$ & $1.92 \pm 0.74$ & $1.07 \pm 0.46$ & 0 & $1.15 \pm 0.37$ & + \\
\hline 2008 & $0.48 \pm 0.27$ & $0.16 \pm 0.16$ & $0.51 \pm 0.25$ & $0.96 \pm 0.54$ & $0.64 \pm 0.45$ & $0.32 \pm 0.32$ & 0 & $1.54 \pm 0.46$ & 0 \\
\hline
\end{tabular}

+-One or several specimens were found beyond counts; ?-no data for this year.

Table 2. Mann-Whitney $\mathrm{U}$ test $(\mathrm{U} / p<0.05)$ for the status of Italian locust populations for every consecutive pair of years in the Kulunda steppe.

\begin{tabular}{|c|c|c|c|c|c|c|c|c|c|}
\hline Year & Aleksandrovskij & Burla & Yarovoe & Platovka & Severka & Pokrovka & Mikhaylovskoye & Bor-Forpost & Ust-Volchikha \\
\hline 1999-2000 & $?$ & $?$ & $\begin{array}{c}41.5 \\
0.0000\end{array}$ & $\begin{array}{c}85 \\
0.00001\end{array}$ & $\begin{array}{c}202.5 \\
0.0328\end{array}$ & $\begin{array}{c}125 \\
0.0003\end{array}$ & $\begin{array}{l}167.5 \\
0.000\end{array}$ & $?$ & n.s. \\
\hline 2000-2001 & $\begin{array}{c}469 \\
0.0000\end{array}$ & $\begin{array}{c}195.5 \\
0.0024\end{array}$ & $\begin{array}{c}196.5 \\
0.0250\end{array}$ & n.s. & $\begin{array}{c}126.5 \\
0.0003\end{array}$ & n.s. & $\begin{array}{c}166 \\
0.0045\end{array}$ & n.s. & n.s. \\
\hline 2001-2002 & n.s. & $\begin{array}{c}165.5 \\
0.0042\end{array}$ & $\begin{array}{c}84.5 \\
0.00001\end{array}$ & $\begin{array}{c}153.5 \\
0.0020\end{array}$ & $\begin{array}{c}94 \\
0.00002\end{array}$ & n.s. & n.s. & n.s. & n.s. \\
\hline 2002-2003 & n.s. & n.s. & n.s. & n.s. & n.s. & $\begin{array}{c}1012 \\
0.0055\end{array}$ & n.s. & n.s. & n.s. \\
\hline
\end{tabular}

?-no data for this pairs; n.s.- not significant difference. 
The seasons with the high locust abundance can be considered as outbreak periods. Our data showed that, in the region, the outbreaks were characterized by the average densities of adults more than 3 ind. per $\mathrm{m}^{2}$. However, intensity and duration of each local outbreak may be quite different. For instance, the maximal registered densities varied very significantly between the populations studied (Tables 1 and 2). As for duration, 5 from 9 populations were characterized by the explicit one-year maximum, while one population (near Platovka) showed the high levels both in 2000 and 2001, and the population near Pokrovka was distinguished by the relatively long outbreak from 2000 until 2002. Two other stages in long-term dynamics of the Italian locust populations can be revealed as well:

(1) A recession, when adults' abundance in a local population in the middle and the end of a summer varies between relatively low and moderate (according our estimation, in the Kulunda steppe, from 0.1 up to 2.0 ind. per $\mathrm{m}^{2}$, perhaps in some cases-up to 3.2). This means that recommendations of some published manuals concerning monitoring and management of pest locusts and grasshoppers $[40,41]$ to organize partial treatments in the next year, when the density of the Italian locust adults is more than 1 ind. per $\mathrm{m}^{2}$, are based on too conservative estimations.

(2) A depression, when density is very low, commonly significantly less than 0.1 ind. per $\mathrm{m}^{2}$. In this case, a population may be stable, but scarce locusts are distributed very sporadically. For instance, in 31 July 2019, I spent about two hours on our main model site in the northern part of the Kulunda steppe (near Aleksandrovskij) finding only 10 adults of the Italian locust and estimated their average density as about 25 ind. per ha (Figure 2).

Besides, there were no evident correlations between species abundance, its morphological characteristics (actually the E/F ratio), and its behavior (Table 3). In 2000, when the Italian locust was very abundant on our main model plot near Aleksandrovskij settlement and there were numerous and dense bands and small swarms, the average level of the E/F ratio corresponded to the transiens status [19]. In 2008, when its abundance was low and there were no bands or swarms, the $\mathrm{E} / \mathrm{F}$ ratio for females corresponded to transiens again (moreover, one female morphologically looked like the gregarious one). Similar discords could be likewise observed on other sites (Table 3) [19]. Our data for 1999-2000 also show that presence of the gregarious form was limited (for all samples-about $4.9 \%$ of females and $7.1 \%$ of males) [19]. This also means that the rate of long (including transborder) migrations during the outbreaks was low.

Thus, the adjacent local populations of the Italian locust could differ significantly in their long-term dynamics patterns. In the south-eastern part of West Siberian Plain, these changes often look like some waves of spatial redistribution of maxima and minima of abundance $[19,20]$. The akin peculiarities of the Italian locust population dynamics were described for the North Caucasus as well [42].

Table 3. Changes of the average densities (ind. per $\mathrm{m}^{2} \pm$ s.e.) and average tegmen length/posterior femur length ratios (E/F \pm s.e.) of the Italian locust on two plots with quite different long-term dynamics.

\begin{tabular}{|c|c|c|c|c|c|c|c|c|}
\hline \multirow[t]{2}{*}{ Year } & \multicolumn{4}{|c|}{ Aleksandrovskij } & \multicolumn{4}{|c|}{ Ust-Volchikha } \\
\hline & Density & $\begin{array}{l}\text { Species } \\
\text { Behavior }\end{array}$ & E/F Females & E/F Males & Density & $\begin{array}{l}\text { Species } \\
\text { Behavior }\end{array}$ & E/F Females & E/F Males \\
\hline 1999 & $?$ & 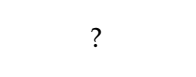 & $?$ & $?$ & $0.32 \pm 0.22$ & $\begin{array}{c}\text { No bands and } \\
\text { swarms }\end{array}$ & $\begin{array}{c}1.576 \pm \\
0.004\end{array}$ & $\begin{array}{c}1.609 \pm \\
0.006\end{array}$ \\
\hline 2000 & $24.32 \pm 2.34$ & $\begin{array}{c}\text { Numerous } \\
\text { bands, small } \\
\text { swarms, active } \\
\text { local flights }\end{array}$ & $\begin{array}{c}1.514 \pm \\
0.016\end{array}$ & $\begin{array}{c}1.539 \pm \\
0.013\end{array}$ & $0.48 \pm 0.27$ & $\begin{array}{l}\text { Very small and } \\
\text { scarce swarms }\end{array}$ & $1.368 \pm 0.010$ & $1.392 \pm 0.012$ \\
\hline 2001 & $2.77 \pm 0.70$ & $\begin{array}{c}\text { No bands and } \\
\text { swarms }\end{array}$ & $1.395 \pm 0.013$ & $\begin{array}{c}1.406 \pm \\
0.018\end{array}$ & $1.60 \pm 0.46$ & $\begin{array}{l}\text { Very small and } \\
\text { scarce swarms }\end{array}$ & $\begin{array}{c}1.473 \pm \\
0.011\end{array}$ & $\begin{array}{c}1.479 \pm \\
0.009\end{array}$ \\
\hline 2008 & $0.48 \pm 0.27$ & $\begin{array}{c}\text { No bands and } \\
\text { swarms }\end{array}$ & $\begin{array}{c}1.484 \pm \\
0.038\end{array}$ & $1.384 \pm 0.024$ & 0 & $\begin{array}{c}\text { No bands and } \\
\text { swarms }\end{array}$ & $?$ & $?$ \\
\hline
\end{tabular}

In bold-the average E/F ratios correspond to the intermediate (transiens) status of the local population; in italics-the solitarious status of the population; ?-no data for this year. 


\subsection{Seasonal Dynamics and Distribution of the Italian Locust Local Population in the Northern Steppe in 2000-2019}

We started to study the dynamics of the Italian locust population in the northern part of the Kulunda steppe (near Aleksandrovskij settlement) in 2000, on 20 June. The steppe areas and the edges of agricultural fields were occupied by numerous hopper bands. These bands mainly consisted of the first stage hoppers (about 95\%) [16]. The average density of locusts was $24.67 \pm 4.42$ ind. per $\mathrm{m}^{2}$ on the steppe plot and $430.4 \pm 161.6$ ind. per $\mathrm{m}^{2}$ on the field edge where some bands concentrated. The density in bands could be more than 1000 ind. per $\mathrm{m}^{2}$, while band areas varied between 2 and $300 \mathrm{~m}^{2}$ [16].

After a week, the bands included the hoppers of all five instars, while the second and third instars dominated. On 5 July, the main part of the population consisted of the fourth instar hoppers; however, it also included many nymphs of the third and fifth instars [16]. The hopper band areas varied between 4 and $3500 \mathrm{~m}^{2}$. On 20 July, adults comprised almost half of the population. The second half included mainly the fifth instar hoppers and a few fourth stage hoppers [16]. Some bands occupied more than 5 ha. On the control plot, the average density was relatively stable [16]. Adults tried to fly, but their flights were limited to meters to dozens of meters. Besides, there were several huge colonies of rooks. Our estimations show that these birds can withdraw about $10-15 \%$ of the locust population [9].

Treatments with fipronil showed very high effectiveness within the $15 \mathrm{~m}$ of the treated swaths-more than $95 \%$ after several days, while on the untreated $15 \mathrm{~m}$ swaths only some weak effects (17-33\% reduction) could be observed only after a week or two [16,43]. This pattern can be explained by extremely low rates of young hopper migrations till the end of June, because there were sufficient quantities of preferred foods. In July, insects (last instars and adults) started to move more actively $[16,43]$.

In 2001, general abundance of the Italian locust decreased, and there were no bands. In the beginning of our studies, on 5 June, the average density of the Italian locust was only $3.41 \pm 0.54$ ind. per $\mathrm{m}^{2}$, while the population mainly consisted of the first stage hoppers (about $87 \%$ ). The early fourth instar hoppers were observed on 15 June, and the first adults-on 5 July. On 15 July, adults comprised about $64 \%$ of the population. Besides, there were also the fourth instar (about 21\%) and fifth instar nymphs (about 15\%). On the control plot, the average density was relatively stable and remained almost the same during the season (on 15 July $-2.77 \pm 0.70$ ind. per $\mathrm{m}^{2}$ ).

Experiments with teflubenzuron showed that this IGR was highly effective in blanket treatments and also within the treated $15 \mathrm{~m}$ swaths (Table 4). Effectiveness was most obvious after about a week which corresponds to the molting rates of hoppers-every 5-7 days [9]. The high levels of effectiveness were observed on treated plots. Untreated swaths were characterized by moderate effectiveness of treatments, usually about $80-84 \%$.

Table 4. Effectiveness (\%) of teflubenzuron treatments (6 June) on the experimental site in the northern part of the Kulunda steppe (near Aleksandrovskij settlement) in 2001.

\begin{tabular}{ccccccccccc}
\hline & Plot & 7 June & 12 June & 13 June & 15 June & 16 June & 23 June & 26 June & 5 July & 15 July \\
\hline \multirow{2}{*}{ Type } & Treated/Untreated & D1 & D6 & D7 & D9 & D10 & D17 & D20 & D29 & D39 \\
\hline \multirow{2}{*}{ 1:1 } & Blanket & 31.4 & 70.0 & 100 & 93.7 & 100 & 100 & 76.0 & 100 & 86.1 \\
& Treated & 57.2 & 81.3 & 100 & 100 & 93.2 & 100 & 100 & 91.7 & 100 \\
& Untreated & 35.7 & 43.8 & 77.5 & 80.3 & 79.5 & 70.8 & 55.0 & 50.0 & 65.4 \\
\multirow{2}{*}{$1: 2$} & Treated & 46.4 & 81.3 & 100 & 96.1 & 100 & 100 & 100 & 100 & 82.7 \\
& Untreated & 57.2 & 62.5 & 70.0 & 56.6 & 86.4 & 66.7 & - & 8.3 & 56.7 \\
\hline \multirow{2}{*}{$1: 3$} & Treated & 14.3 & 70.0 & 76.0 & 81.1 & 90.1 & 86.8 & 100 & 33.3 & 86.1 \\
& Untreated & 14.3 & 10.0 & 52.0 & 36.9 & 78.2 & 33.9 & 4.0 & - & 58.4 \\
\hline
\end{tabular}

These experiments showed that teflubenzuron (like other IGRs) could be very suitable for the Italian locust management in the steppes of South Siberia. However, the efficacy 
of the barrier treatments with relatively wide untreated swaths was low. Hence, blanket application and barrier treatments with narrow equal alternating swaths may be optimal.

\subsection{The Italian Locust and Rare Orthopteran Species}

Among local species of Orthoptera, Saga pedo (Pallas), Gampsocleis glabra (Herbst), and Onconotus servillei (Fischer de Waldheim) are on the IUCN Red List of Threatened Species [44]. The first species is also in the Red Book of the Russian Federation. Besides, in the south-western part of West Siberian Plain, there are several rare species of Orthoptera. Recently, we analyzed shifts in rare acridid species distribution over the Baraba and $\mathrm{Ku}-$ lunda steppes [45]. At least two grasshoppers, namely, Notostaurus albicornis (Eversmann) and Mesasippus arenosus (Bey-Bienko), could be found in the habitats where the Italian locust may be very abundant. Miramiola pusilla (Miram) (Tettigoniidae) and Aeropedellus baliolus Mistshenko. (Acrididae) may be observed on these plots as well. This means, in the steppe habitats, anti-locust treatments can result in decreasing and even elimination of rare species populations.

Rare species were found on almost all sites studied or just nearby (see Section 2.2), except vicinities of Platovka and Pokrovka (Table 5). G. glabra was the most common rare species in the steppe habitats. M. pusilla was found on four sites, both Saga pedo and A. baliolus - on two, and N. albicornis occurred only in one place.

Table 5. Occurrence of rare Orthoptera on sites studied in the Kulunda steppe.

\begin{tabular}{|c|c|c|c|c|c|c|c|c|c|}
\hline Year & Aleksandrovskij & Burla & Yarovoe & Platovka & Severka & Pokrovka & Mikhaylovskoye & $\begin{array}{c}\text { Bor- } \\
\text { Forpost }\end{array}$ & $\begin{array}{c}\text { Ust- } \\
\text { Volchikha }\end{array}$ \\
\hline 1992 & $?$ & $?$ & $\begin{array}{l}\mathrm{AB}, \\
\mathrm{NA}\end{array}$ & & & & & $?$ & $?$ \\
\hline 1999 & $?$ & $?$ & $\mathrm{MP}$ & & & & & $?$ & \\
\hline 2000 & $\mathrm{GG}, \mathrm{MP}^{\mathrm{b}}$ & & $\begin{array}{l}\mathrm{AB}, \\
\mathrm{NA}\end{array}$ & & & & & & \\
\hline 2001 & $\mathrm{AB}, \mathrm{GG}^{\mathrm{c}}, \mathrm{MP}$ & GG & NA & & & & GG, SP a & & \\
\hline 2002 & $\mathrm{AB}, \mathrm{MP}^{\mathrm{d}}$ & & $\mathrm{AB}$ & & & & & & \\
\hline \multicolumn{10}{|l|}{2003} \\
\hline 2004 & GG, MP e & & & & & & & & \\
\hline 2005 & GG & GG & $\mathrm{AB}$ & & & & & GG, SP & \\
\hline 2006 & GG & & $\begin{array}{l}\mathrm{AB} \\
\mathrm{MP}\end{array}$ & & $\mathrm{MP}^{\mathrm{a}}$ & & & & \\
\hline 2007 & & & $\mathrm{MP}$ & & & & & & $\mathrm{GG}^{\mathrm{a}}$ \\
\hline 2008 & $\mathrm{GG}^{\mathrm{e}}, \mathrm{MP}^{\mathrm{e}}$ & & GG & & & & GG & GG & \\
\hline 2015 & GG & & MP & & & & & MP & \\
\hline
\end{tabular}

$\mathrm{AB}$-Aeropedellus baliolus Mistsh.; GG—Gampsocleis glabra (Hbst.); MP—Miramiolla pusilla (Mir.); NA—Notostaurus albicornis (Ev.); SP—Saga pedo (Pall.); ${ }^{\mathrm{a}}$ - the species was found on some adjacent plot; ${ }^{\mathrm{b}}$ - the species was also found after the fipronil treatment (30 days since-20 July); ${ }^{\mathrm{C}}$ - the species was also found after the teflubenzuron treatment (39 days since-15 July); ${ }^{\mathrm{d}}$ - the species was found only on the plot treated by the synthetic pyrethroid in 2001; e-the species was also found on the plots treated by the synthetic pyrethroid in 2001; ?-no data for this year.

In 2000 and 2001 anti-locust treatments in the northern part of the Kulunda steppe (near Aleksandrovskij settlement) did not result in elimination of the local populations ofrare Orthoptera. Three species, namely, A. baliolus, G. glabra, and M. pusilla, were found more or less often. Moreover, in 2000, the last species was observed on the treated swath after a month. In 2001, a similar situation was registered for G. glabra. Later, in 2002, 2004, and 2008, M. pusilla was also found on the plots treated by the synthetic pyrethroid in 2001. This means some localized treatments with acridicides (especially the barrier ones) do not destroy significantly populations of rare Orthoptera. 


\section{Discussion}

Our studies of the Italian locust ecology and distribution as well as studies of our colleagues during last two decades resulted in revealing several dilemmas concerning approaches to monitor, manage, and forecast its population dynamics in time and space.

4.1. May We Use for the Italian Locust Approaches and Technologies Developed for the Desert and Migratory Locusts or Not?

Nowadays, the Italian locust is the only locust species mainly associated with temperate grasslands, namely, steppes and northern semi-deserts. The main breeding (outbreak) areas of the desert and migratory locusts as well as some other important pests are in the tropical and subtropical regions $[2,3,9,46]$. This is why many ecological and biological peculiarities of the Italian locust are quite different $[1,2,9]$. The species is univoltine and is, even during depressions (see Section 3.4), often widely distributed across different ecosystems, especially in the dry steppes and the semi-deserts. Its behavior during outbreaks is common for locusts, but areas occupied by bands and swarms and ranges of dispersal rates are relatively limited, while outbreaks are relatively short and commonly can last for one or several years. This means that, in steppes and semi-deserts, it is almost impossible to identify precisely preferred breeding areas of the Italian locust [47]. In the 1950s K.A. Vasil'ev [5] tried to delimit some such breeding areas in Central Kazakhstan, but in reality, he described several plots where gregarization already had started.

In the steppes, the species occurs usually in all applicable habitats, but their local populations are often scarce and characterized by low abundance, while, in the semi-deserts, its populations may be usually relatively abundant for many decades $[4,9,12,36]$. Besides, the Italian locust long-term dynamics may be described as quite specific. In the dynamics of the migratory and desert locust, several main periods, namely, plagues, outbreaks, and recessions (and sometimes-also peak plagues, upsurges, and deep recessions), may be often distinguished [48-50]. In the dynamics of the Italian locust, plagues are extremely rare. Only last huge outbreaks in the end of 20th century can be qualified as the plague. Actually, numerous outbreaks of C. italicus were and are usually limited in space and time, and their decline may result in either the recession or the depression characterized by stable populations with extremely low average densities and scarce individuals' distribution (see Section 3.4). If a population drops off, the recession may transform into the depression. On the contrary, if a population with very low abundance begins to increase (and may be crowding), the depression may transform into the recession.

One may suggest that, in this situation, we should monitor all habitats colonized by the Italian locust across huge territories of its range and, inside the range, try to check carefully populations with relatively high densities of adults (probably, more than 1 ind. per $\mathrm{m}^{2}$ in the steppes and 5-7 ind. per $\mathrm{m}^{2}$ in the semi-deserts). Therefore, many (or all) approaches developed to monitor and control the desert and migratory locusts are not applicable for the Italian locust, or they should be adapted for the situation.

\subsection{Monitoring, Management, and Forecasting: Is the Regional Level of Exploration Enough or Not?}

The environmental factors and the biological and ecological characteristics of each species can significantly vary in time and space so that their relations can be revealed only by consistent explorations of species populations across its total range [3]. This is important for both potential pest species and rare forms. Actually, in many cases, pest infestations can be small-scale events, localized in space and time and dependent on local conditions [51].

Local outbreaks of the Italian locust usually start after several years with warm and relatively dry periods in the end of spring and in the beginning of summer, while their regressions are mainly associated with cool and rainy summers $[3,5,10,11]$. However, rates of increasing and decreasing, gregarization and dissociation in local populations may be quite different $[4,9,16]$ and look like depending on local environmental conditions. 
As a result, the local outbreak in one population can develop faster (or slower) than the outbreaks in adjacent colonies. Some similar trends can be revealed for regression.

However, forecasting systems are usually based on the regional generalization and simplification of assessment data $[32,33,40,41]$, while local colonies of $C$. italicus can be significantly different in their ecology (including dynamics) and diversity (including intrapopulation characteristics) $[4,9,19,52]$. This means that we should use often different management procedures for two neighboring local populations of this species; moreover, in many cases, we are not able to delimit a local population without special studies [52].

We should reveal seasonal and long-term dynamics of local populations (ideally, all such populations) and try to evaluate their temporal patterns relative to climatic and ecosystem changes and to peculiarities of each colony. We should reveal also spatial structures (patches and gaps, distances, population connections, barriers and corridors) and local dispersal systems (parameters of emigration and immigration).

These substantial localized variations in population dynamics mean large scale forecasting of Italian locust upsurges and declines is very difficult. Local forecasting and management may be possible based on increased understanding of local population dynamics, but having local knowledge in the many parts of its vast range and in quite different habitats would require substantial effort that at present is just not possible. However, if we eventually understand the exact patterns of spatial population structures, we will be able to understand, at least, some peculiarities of dynamic patterns in each local population.

\subsection{Monitoring, Management, and Forecasting: When Should We Begin (or End) to Trouble or When Not?}

National and international plant protection services usually use one or several parameters to determine when and where control operations should start. J.A. Lockwood [53] designated this approach as the administrative one. For example, in the USA and in Russia, these operations usually begin when population densities of grasshoppers reach more than 9-10 ind. per $\mathrm{m}^{2}[1,40,41]$. In the case of the Italian locust, according different authors $[1,9,40,41]$, the critical values for hoppers are about $2-5$ and for adults- about 1 ind. per $\mathrm{m}^{2}$. However, these levels of density are actually too low [53,54]. For instance, in the dry steppes of Central Kazakhstan, the average adult density of solitarious populations of C. italicus could be more than 2-7 ind. per $\mathrm{m}^{2}$ [5], while in the semi-deserts and the mountain steppes of East Kazakhstan, this density might reach 26 ind. per $\mathrm{m}^{2}$ [36]. This means that the critical values for the Italian locust may vary remarkably from one population to another and from one year to another and can depend on numerous parameters (climatic fluctuations, vegetation and soil dynamics, human resources, etc.) Moreover, density effects can be also very notable [55]. They may be rather complicated and more or less unpredictable due to complex nature of ecosystem and population dynamics. Besides, according the catastrophe theory [56], small variations in weather may result in different population dynamics. There are no exact criteria to distinguish consecutive stages of long-term dynamics of locusts as well [50].

This means in many cases we do not have applicable criteria where, when, why and how to monitor and control early infestations [57]. This is especially important for the Italian locust, since its populations between outbreaks are sprawling and scarce. Some formal criteria (densities, band formation, morphometric indices, etc.) may mean almost nothing, because (1) critical values can vary significantly between different ecosystems and between different periods, (2) some traits of gregarization may be revealed during regressions when a population density is relatively low, (3) small changes can result in different dynamics [55,56], and (4) at least in some cases usual criteria do not correlate [19] (see also Section 3.4).

\subsection{Treatments: When Do Barriers Work and When Not?}

Barrier treatments are widely used for locust populations management in different regions. The so-called reduced area and agent insecticide treatments (RAATs) technology often result in evident decline of locust densities, preserve some level of biological diver- 
sity, and significantly decrease direct expenses $[58,59]$. However, the experimental barrier treatment with fipronil showed that its general efficacy was low [16] (see also Section 3.5). The hopper bands usually stayed on the steppe plots with well-developed vegetation, did not move or moved only over the very short distances (about several meters per day) and, thus, did not actively cross over the treated areas. In 2001 the experimental treatments with teflubenzuron showed the similar pattern. The maximal effect on the untreated swaths was observed in the middle of June (after 9-10 days since the treatment) (Table 4), and it was relatively significant only for the experiment with equal narrow swaths. When hopper bands begin to move more or less rapidly $[5,60]$, barrier treatments, especially with low dosage, may be very effective. Besides, the developmental stages of hoppers are also important, because one can use low dosage of an insecticide against young hoppers $[16,60,61]$, but such hoppers usually move slowly $[5,60]$. This means that we should take into consideration not only pest abundance, situations with biodiversity, and management costs but also general conditions of ecological systems and local population statuses.

\subsection{Treatments: Can We Preserve Local Populations of Rare Orthoptera or Not?}

Steppes and other grasslands are ecosystems where both pest acridids and rare Orthoptera are distributed [62-65]. This means there is a clash between approaches to manage pest populations (to monitor, forecast and control their outbreaks) and to preserve rare forms and their populations. In the steppes of the south-eastern part of West Siberian Plain, some rare species may occur in the same habitats and for the same time as the Italian locust, especially its bands $[20,45,62]$. Thus, acridicide treatments against the bands could result in damage or full elimination of local populations of rare Orthoptera, such as $S$. pedo, M. pusilla or A. baliolus. However, our observations show that the harmful effects of acridicides on rare steppe species of Orthoptera may be relatively weak (cf. Section 3.6), when treatments are localized in space, i.e., do not cover all area of a habitat, e.g., the RAATs type or even simple variants of barrier applications.

\section{Conclusions}

The Italian locust is characterized by populations, which are widely distributed across its range and through quite different types of grasslands. In the dry steppes and especially in the semi-deserts, it may colonize all or almost all applicable habitats and may be abundant, while in the forest-steppes and the northern and typical steppes, between outbreaks, its abundance is commonly low or extremely low, and often surveyors may observe very few specimens during several hours of observations. Its local populations often respond differently to climatic fluctuations and changes of human activity. In the steppes, hopper bands often move very slowly, or they stay in one place during several days or even weeks, while adults prefer very short local flights. Besides, the Italian locust often colonize the same grasslands as rare orthopteran species. This is why we cannot use many of the ideas, approaches, and technologies suggested for the desert and migratory locust to monitor, supervise, and control populations of $C$. italicus.

Recently we suggested to change considerably the strategy and tactics to avoid the Italian locust outbreaks [66]:

(1) Crucial parts of the range, habitats, and time lapses should be determined for the species across all species range, each region, and landscape.

(2) New approaches have to be elaborated to manage populations on the landscape scale and to treat agricultural fields and rangelands.

(3) Agricultural technologies per se ought to be modified significantly. For instance, in grasslands, overgrazing should be minimized, and restoration of abandoned fields that commonly harbor $C$. italicus should be accelerated.

(4) Information technologies, especially associated with big data storage and analysis, ecologo-geographic modeling, global information systems, and remote sensing, should become the main basis for monitoring, supervising and forecasting (see also [67-69]). 
(5) New approaches should be very important for field assessments of the Italian locust populations as well. For instance, real time observations by using unmanned aerial vehicles are very hopeful.

Besides, one should consider that the Italian locust is the member of grasshoppers' group (Acridoidea), and these insects are common inhabitants of all or almost all grasslands. They often considered as one of the most important consumers in steppes, prairies, savannas, semi-deserts, and even deserts [70-72]. Moreover, grasshoppers may enhance net primary production over years [73]. In the dry steppes and the semi-deserts, even between outbreaks, the Italian locust may consume significant part of aboveground vegetation, to damage growing points of sagebrushes and to accelerate their growth [36]. During outbreaks the species can also change considerably fluxes of some chemical elements in the steppe ecosystems [74]. One may also hypothesize that the Italian locust can also interact with other species of Orthoptera in ecosystems, and some variations in its populations should result in changes of orthopteran assemblages and populations, including colonies of rare species. In any case, attempts to control the Italian locust populations affect colonies of other species, either positively or negatively. This means we should alter widely distributed common management approaches to the holistic ones arising not only from exploration of species populations or their assemblages but also from investigations of ecosystemsper se and their changes in space and time.

Funding: These studies were financially supported by the joint programme of the Russian Foundation for Basic Researches and the Government of Novosibirsk Region (18-416-540001 and 20-416-540004) and also by the Federal Fundamental Scientific Research Programme (FWGS-2021-0002).

Institutional Review Board Statement: Not applicable.

Informed Consent Statement: Not applicable.

Data Availability Statement: Not applicable.

Acknowledgments: I thank all my colleagues and students (especially O. Denisova, O. Efremova, O. Ermolaeva, K. Popova, and I. Vanjkova) for their valuable help during collecting field data. I am also indebted to all companions during our numerous field trips. I wish to express special thanks to the late L.L. Mistshenko and the late I.V. Stebaev for their advices and cooperation and to L.B. Pshenitsyna for indentification of plant species. Finally, to the late V.I. Strizhak, K.K. Musinov, N.I. Vastshenko, and A.N. Shedenko, I am indebted for helping us with organization of experimental treatments in 2000 and 2001. I also thank two anonymous reviewers for their valuable comments and proposals.

Conflicts of Interest: The author declares no conflict of interest.

\section{References}

1. Latchininsky, A.V.; Sergeev, M.G.; Childebaev, M.K.; Chernijakhovskij, M.E.; Lockwood, J.A.; Kambulin, V.E.; Gapparov, F.A. The Grasshoppers of Kazakhstan, Middle Asia and Adjacent Territories; Association for Applied Acridology International \& University of Wyoming: Laramie, WY, USA, 2002; p. vii + 387. (In Russian)

2. Zhang, L.; Lecoq, M.; Latchininsky, A.; Hunter, D. Locust and grasshopper management. Ann. Rev. Entomol. 2019, 64, 15-34. [CrossRef]

3. Uvarov, B.P. Grasshoppers and Locusts; Centre for Overseas Pest Research: London, UK, 1977; Volume 2, p. 613.

4. Sergeev, M.G.; Denisova, O.V.; Vanjkova, I.A. How do spatial population structures affect acridid management? In Grasshoppers and Grassland Health: Managing Grasshopper Outbreaks without Risking Environmental Disaster; Lockwood, J.A., Latchininsky, A.V., Sergeev, M.G., Eds.; Kluwer Academic Publishers: Dordrecht, The Netherlands; Boston, MA, USA; London, UK, 2000; pp. 71-87. [CrossRef]

5. Vasil'ev, K.A. The Italian locust (Calliptamus italicus L.) in Central Kazakhstan. Trudy Nauchno-Issledovatelskogo Inst. Zastshity Rastenij 1962, 7, 123-190. (In Russian)

6. Bunin, L.D. The Italian Locust (Calliptamus italicus L.) in the Soil-Saving Agriculture Zone in East. Kazakhstan and Development of Treatments. Ph.D. Thesis, VIZR, Leningrad, Russia, 1979; p. 24. (In Russian)

7. Azhbenov, V.K. Outbreaks and migrations of locusts in Kazakhstan. Steppe Bull. 2000, 6, 16-20. (In Russian)

8. Vasil'ev, K.A. Phases of the Italian locust (Calliptamus italicus L.). Proc. USSR Acad. Sci. 1950, 74, 639-642. (In Russian) 
9. Sergeev, M.G.; Childebaev, M.K.; Van’kova, I.A.; Gapparov, F.A.; Kambulin, V.E.; Kokanova, E.; Latchininsky, A.V.; Pshenitsyna, L.B.; Temreshev, I.I.; Chernijakhovskij, M.E.; et al. The Italian Locust [Calliptamus italicus (Linnaeus, 1758)]: Morphology, Distribution, Ecology, Population Management, Draft Version; FAO: Rome, Italy, 2016; p. 330. Available online: http:/ /www.fao.org/locusts-cca/ bioecology/italian-locust-cit/en/ (accessed on 21 December 2020). (In Russian)

10. Stolyarov, M.V. Massenvermehrungen von Calliptamus italicus L. in Südrussland im zwanzigsten Jahrhundert. Articulata 2000, 15, 99-108.

11. Stolyarov, M.V. Cyclicity and some characteristics of mass reproduction of Calliptamus italicus L. in Southern Russia. Russ. J. Ecol. 2000, 31, 43-48. [CrossRef]

12. Sergeev, M.G.; Van'kova, I.A. Zonal-landscape distribution of population groups of Calliptamus italicus L. (Insecta, Orthoptera, Acrididae). Sib. J. Ecol. 1996, 3, 219-225.

13. Isachenko, A.G. Landscapes of the USSR; Leningrad University Publ.: Leningrad, Russia, 1985; p. 320. (In Russian)

14. Smelansky, I.E.; Tishkov, A.A. The steppe biome in Russia: Ecosystem services, conservation status, and actual challenges. In Eurasian Steppes. Ecological Problems and Livelihoods in A Changing World; Werger, M.J.A., van Staalduinen, M.A., Eds.; Plant and Vegetation; Springer Science+Business Media, B.V.: Dordrecht, The Netherlands, 2012; Volume 6, pp. 45-101. [CrossRef]

15. Chibilev, A.A. Steppe Eurasia: A Regional Review of Natural Diversity; Institute of Steppe and RGS: Moscow, Russia; Orenburg, Russia, 2017; p. 324. (In Russian)

16. Sergeev, M.G.; Van'kova, I.A. The dynamics of a local population of the Italian locust (Calliptamus italicus L.) in an anthropogenic landscape. Contemp. Probl. Ecol. 2008, 1, 88-95. [CrossRef]

17. Sergeev, M.G. Patterns of Orthoptera Distribution in North Asia; Nauka Publ.: Novosibirsk, Russia, 1986; p. 237. (In Russian)

18. Gause, G.F. Studies on the ecology of the Orthoptera. Ecology 1930, 11, 307-325. [CrossRef]

19. Sergeev, M.G.; Van'kova, I.A. Dynamics of the Italian locust Calliptamus italicus L. population in the southeast of the West Siberian Plain. Contemp. Probl. Ecol. 2008, 1, 204-209. [CrossRef]

20. Sergeev, M.G. Distribution patterns of grasshoppers and their kin over the Eurasian Steppes. Insects 2021, 12, 77. [CrossRef] [PubMed]

21. Henderson, C.F.; Tilton, E.W. Tests with acaricides against the brown wheat mite. J. Econ. Entomol. 1955, 48, 157-161. [CrossRef]

22. Hammer, Ø.; Harper, D.A.T.; Ryan, P.D. PAST: Paleontological statistics software package for education and data analysis. Palaeontol. Electron. 2001, 4, 9.

23. Ili'ina, I.S.; Lapshina, E.I.; Lavrenko, N.N.; Meltser, L.I.; Romanova, E.A.; Bogojavlenskij, B.A.; Mahno, V.D. Vegetation of West Siberian Plain; Nauka Pub.: Novosibirsk, Russia, 1985; p. 251. (In Russian)

24. Sergeev, M.G. Metapopulations of locusts and grasshoppers: Spatial structures, their dynamics and early warning systems. In New Strategies in Locust Control; Krall, S., Peveling, R., Ba Diallo, D., Eds.; Birkhauser Verlag: Basel, Switzerland, 1997; pp. 75-80. [CrossRef]

25. Bugaev, G.S. Habitat distribution of grasshoppers in the zone of band pine forests in North-East Kazakhstan. Vestn. Selskokhoziastvennoj Nauk. Kazakhstana 1977, 6, 37-40. (In Russian)

26. Bey-Bienko, G.J. The zonal and ecological distribution of Acrididae in West Siberian and Zaisan Plains. Tr. po Zastshite Rasteniy Ser. Entomol. 1930, 1, 51-90. (In Russian)

27. Lindemann, K. The Italian Locust in Voronezh Province; V.I. Isaev Publ.: Voronezh, Russia, 1892; p. 52. (In Russian)

28. Filip'ev, I.N. Common pests. Grasshoppers. Acridoidea. Tr. po Prikl. Entomol. 1926, 13, 57-176. (In Russian)

29. Predtechensky, S.A.; Zhdanov, S.P.; Popova, A.A. Pest locusts in the USSR. Tr. po Zastshite Rastenij. Ser. Entomol. 1935, 18, 1-168. (In Russian)

30. Berezhkov, R.P. The Grasshoppers of West Siberia; Tomsk University Publ.: Tomsk, Russia, 1956; p. 174. (In Russian)

31. Borisenkov, E.P.; Pasetskij, V.M. Thousand-Year Chronicle of Extraordinary Natural Phenomena; Mysl Publ.: Moscow, Russia, 1988; p. 524. (In Russian)

32. Govorov, D.N.; Zhivykh, A.V. (Eds.) The Report on Phytosanitary Conditions of Crops in the Russian Federation in 2018 and Pest Forecasts for 2019; Rosselkhozcenter: Moscow, Russia, 2019; p. 900. (In Russian)

33. Govorov, D.N.; Zhivykh, A.V. (Eds.) The Report on Phytosanitary Conditions of Crops in the Russian Federation in 2019 and Pest Forecasts for 2020; Rosselkhozcenter: Moscow, Russia, 2020; p. 897. (In Russian)

34. Kushalieva, S.A.; Avtaeva, T.A. Peculiarities of the Italian locust (Calliptamus italicus) ecology in the semi-desert life zone of the Chechen Republic. Her. Kursk State Agric. Acad. 2019, 6, 73-78. (In Russian)

35. Kamynina, L.D. Locusts in the Altai Region. Steppe Bull. 2000, 6, 9-10. (In Russian)

36. Chetyrkina, I.A. The Italian locust Calliptamus italicus L. in East Kazakhstan. Horae Soc. Entomol. Unionis Sov. 1958, 46, 5-67. (In Russian)

37. Raevskij, V.G. Observation of the Italian locust (Calliptamus italicus L.) in the Slavgorod county in 1922. Rep. Sib. Entomol. Bur. 1924, 2, 53-58. (In Russian)

38. Troitskij, D. Pest grasshoppers of the Semipalatinsk Region in 1912. Needs West. Sib. Agric. 1914, 1, 23-49. (In Russian)

39. Tsyplenkov, E.P. Pest. Grasshoppers in the USSR; Kolos Publ.: Leningrad, Russia, 1970; p. 271. (In Russian)

40. Naumovich, O.N.; Stolyarov, M.V.; Dolzhenko, V.I.; Nikulin, A.A.; Alekhin, V.T. Recommendation on Monitoring and Management of Pest Grasshoppers; Kolos: Moscow, Russia, 2000; p. 21. (In Russian) 
41. Dolzhenko, V.I.; Naumovich, O.N.; Nikulin, A.A. Pest Grasshoppers; Plant Protection and Quarantine: Moscow, Russia, 2003 ; p. 28. (In Russian)

42. Kovalenkov, V.G.; Kuznetsova, O.V. How the Italian locust outbreak may be stopped. Plant. Prot. Quar. 2011, 9, 14-17. (In Russian)

43. Sergeev, M.G.; Latchininsky, A.V.; Duranton, J.-F. Possibilities of fipronil (Adonis) application in Siberia. Plant. Prot. Quar. 2002, 3, 19-20. (In Russian)

44. IUCN. The IUCN Red List of Threatened Species. Version 2020-3. 2021. Available online: https://www.iucnredlist.org (accessed on 15 January 2021).

45. Popova, K.V.; Molodtsov, V.V.; Sergeev, M.G. Rare grasshoppers (Orthoptera, Acridoidea) of the Baraba and Kulunda steppes (South Siberia). Acta Biol. Sib. 2020, 6, 595-609. [CrossRef]

46. Le Gall, M.; Overson, R.; Cease, A. A global review on locusts (Orthoptera: Acrididae) and their interactions with livestock grazing practices. Front. Ecol. Evol. 2019, 7, 263. [CrossRef]

47. Uvarov, B.P. Locusts and Grasshoppers; Promizdat: Moscow, Russia; Leningrad, Russia, 1927; p. 306. (In Russian)

48. Hemming, C.F.; Popov, G.B.; Roffey, J.; Waloff, Z. Characteristics of desert locust plague upsurges. Phil. Trans. R. Soc. Lond. B 1979, 287, 375-386. [CrossRef]

49. Magor, J.I. Locust glossary. In Desert Locust Control with Existing Techniques: An Evaluation of Strategies; van Huis, A., Ed.; Wageningen Agricultural University: Wageningen, The Netherlands, 1994; pp. 119-127.

50. Magor, J.I.; Lecoq, M.; Hunter, D.M. Preventive control and desert locust plagues. Crop. Prot. 2008, 27, 1527-1533. [CrossRef]

51. Zimmerman, K.; Lockwood, J.A.; Latchininsky, A.V. A spatial, Markovian model of rangeland grasshopper (Orthoptera; Acrididae) population dynamics: Do long-term benefits justify suppression of infestations? Environ. Entomol. 2004, 33, 257-266. [CrossRef]

52. Kazakova, I.G.; Sergeev, M.G. The problem of delimitation of grasshopper populations. Sib. J. Ecol. 1997, 4, 315-321. (In Russian)

53. Lockwood, J.A. Rangeland grasshopper ecology. In The Bionomics of Grasshoppers, Katydids and Their Kin; Gangwere, S.K., Muralirangan, M.C., Muralirangan, M., Eds.; CAB International: Oxon, UK; NewYork, NY, USA, 1997; pp. 129-146.

54. Joern, A. What are the consequences of non-liner ecological interactions for grasshopper control strategies? In Grasshoppers and Grassland Health: Managing Grasshopper Outbreaks Without Risking Environmental Disaster; Lockwood, J.A., Latchininsky, A.V., Sergeev, M.G., Eds.; Kluwer Academic Publishers: Dordrecht, The Netherlands; Boston, MA, USA; London, UK, 2000; pp. 131-144. [CrossRef]

55. Uvarov, B.P. Grasshoppers and Locusts; Cambridge University Press: London, UK; New York, NY, USA; Ibadan, Nigeria, 1966; Volume 1, p. xi +481 .

56. Lockwood, J.A.; Lockwood, D.R. Catastrophe theory: A unified paradigm for rangeland ecosystem dynamics. J. Range Manag. 1993, 46, 282-288. [CrossRef]

57. van Huis, A. Can we prevent desert locust plagues? In New Strategies in Locust Control; Krall, S., Peveling, R., Ba Diallo, D., Eds.; Birkhauser Verlag: Basel, Switzerland, 1997; pp. 453-459. [CrossRef]

58. Lockwood, J.A.; Schell, S.P. Decreasing economic and environmental costs through Reduced Area and Agent Insecticide Treatments (RAATs) for the control of rangeland grasshoppers: Empirical results and their implications for pest management. J. Orthoptera Res. 1997, 6, 19-32. [CrossRef]

59. Latchininsky, A.V.; Lockwood, J.A.; Sergeev, M.G. Some experience to control grasshoppers in the North American prairies. Plant. Prot. Quar. 1999, 8, 12-14. (In Russian)

60. Wilps, H.; Levchenko, V.; Vernigor, A. Field trials with imidacloprid (Confidor) on the Italian locust Calliptamus italicus in Kazakhstan. J. Appl. Entomol. 2002, 126, 436-443. [CrossRef]

61. Sobolev, N.N.; Sergeev, M.G. Population dynamics of grasshoppers (Orthoptera, Acridoidea) in the agricultural ecosystems of North Kazakhstan. In Human Influences on Insects' Assemblages; Zolotarenko, G.S., Ed.; Nauka Publ.: Novosibirsk, Russia, 1985; pp. 96-104. (In Russian)

62. Sergeev, M.G. La sécheresse et les schémas de distribution des criquets en Asie centrale et septentrionale. Sécheresse 1996, 7, 129-132.

63. Samways, M.J.; Lockwood, J.A. Orthoptera conservation: Pests and paradoxes. J. Insect Conserv. 1998, 2, 143-149. [CrossRef]

64. Sergeev, M.G. Conservation of orthopteran biological diversity relative to landscape change in temperate Eurasia. J. Insect Conserv. 1998, 2, 247-252. [CrossRef]

65. Samways, M.J. Can locust control be compatible with conserving biodiversity? In Grasshoppers and Grassland Health: Managing Grasshopper Outbreaks Without Risking Environmental Disaster; Lockwood, J.A., Latchininsky, A.V., Sergeev, M.G., Eds.; Kluwer Academic Publishers: Dordrecht, The Netherlands; Boston, MA, USA; London, UK, 2000; pp. 173-179. [CrossRef]

66. Latchininsky, A.V.; Sergeev, M.G. The Italian locust—Calliptamus italicus (Linnaeus) (Orthoptera): A quarter of a century after. Metaleptea 2018, 38, 47-48.

67. Latchininsky, A.V. Locusts and remote sensing: A review. J. Appl. Remote Sens. 2013, 7, 075099. [CrossRef]

68. Tronin, A.A.; Gornyy, V.I.; Kiselev, A.V.; Kritsuk, S.G.; Latypov, I.S. Forecasting of locust mass breeding by using satellite data. Curr. Probl. Remote Sens. Earth Space 2014, 11, 37-50.

69. Klein, I.; Oppelt, N.; Kuenzer, C. Application of remote sensing data for locust research and management-A review. Insects 2021, 12, 233. [CrossRef] [PubMed] 
70. Stebaev, I.V.; Gukasian, A.B. Orthoptera (Tettigonoidea and Acrididae) as stimulators of microbiological processes of decomposition and mineralization of phytomass in the meadow steppes of West Siberia. Zool. Zh. 1963, 42, 216-221. (In Russian)

71. Gandar, M.V. The dynamics and trophic ecology of grasshoppers (Acridoidea) in a South African savanna. Oecologia 1982, 54, 370-378. [CrossRef] [PubMed]

72. Hewitt, G.B.; Onsager, J.A. A method for forecasting potential losses from grasshopper feeding on northern mixed prairie forages. J. Range Manag. 1982, 35, 53-57. [CrossRef]

73. Belovsky, G.E. Do grasshoppers diminish grassland productivity? In Grasshoppers and Grassland Health: Managing Grasshopper Outbreaks without Risking Environmental Disaster; Lockwood, J.A., Latchininsky, A.V., Sergeev, M.G., Eds.; Kluwer Academic Publishers: Dordrecht, The Netherlands; Boston, MA, USA; London, UK, 2000; pp. 7-29. [CrossRef]

74. Pshenitsyna, L.B.; Sergeev, M.G.; Koutsenogij, K.P.; Kovalskaja, G.A.; Chankina, O.V. Biogeochemical role of the Italian locust Calliptamusitalicus L. (Orthoptera, Acrididae). In XII Congress of Russian Entomological Society (Saint Petersburg, Russia, 19-24 August, 2002). Abstracts; Russian Entomological Society: Saint Petersburg, Russia, 2002; pp. 299-300. (In Russian) 